\title{
THE COMPETITIVENESS OF HIGHER EDUCATION OF UKRAINE ACCORDING TO THE INTERNATIONAL DIMENSION
}

\author{
Ilona TSARENKO', \\ Kirovohrad National Technical University, Ukraine
}

\begin{abstract}
The purpose of research is evaluation of competitiveness of higher education of Ukraine in comparison with the foreign countries and under the influence of the globalization of market environment. The evaluation of the level of competitiveness of higher education in Ukraine on the modern stage under the influence of the globalization transformation and in the light of international comparisons is investigated insufficiently, which makes up for the purpose and objectives of this research. Methodology. The research is based on a comparison of the data, which are set out in the international reports about the competitiveness of countries in the world, in particular about the higher education. The analysis of the degree of researching the problem of competitiveness of higher education in the works of scientists is made in advance. Results of the research showed that the main components of pillar «High education and training» of the Global Competitiveness Index, namely: secondary education enrollment, tertiary education enrollment, quality of the education system, quality of math and science education, quality of management schools, internet access in schools, availability of research and training services and extent of staff training. The analysis of the dynamics of the indicator "Higher education and training" of Global Competitiveness Index is made for Ukraine and the other countries, which is showed the following: in the last five years the highest index of higher education and training belongs to Finland, the score of which, in the dynamics, significantly increases, concerning Ukraine, it among 132 countries takes $40^{\text {th }}$ place, that is top 50 countries with the highest ranking of the competitiveness of higher education and training, this position for Ukraine is stable, with the exception of 2011, when the position was reduced to 51 in the rankings. Furthermore, in 2014 Ukraine's rating has increased in comparison with other years. Then in more detail the macroeconomic indicators of Ukraine and Finland were analyzed. The main indicators of the level of funding of higher education in different countries have been investigated (total expenditure on education, public expenditure on higher education of GDP, total expenditure on education per capita, expenditure per student per year, personal computers per 100 population, internet users per 100 population), by the results the relevant conclusions are made. The most influential world rankings such as the Shanghai ranking, ranking QS and Times Higher Education World University Ranking are considered. The analysis of the positions of Ukrainian higher educational institutions, which are included in these rankings, is proposed, namely Taras Shevchenko National University of Kyiv (placed 421-430) and V.N. Karazin Kharkiv National University (placed 481-490). Additionally, the principles of improving the competitiveness of higher education are explored. Value/ originality. The obtained results showed, that it is necessary to develop an integrated evaluation methodology of the competitive positions of higher education of Ukraine.
\end{abstract}

Key words: Global Competitiveness Index, Higher education and training, efficiency-driven economies, funding provision, rating, the index of mobility.

JEL Classification: 123, 128, 138, G24

\section{Introduction}

Institute of Higher Education is the formative system for the prospects of further development of the country in the direction of the economic growth, increasing social and cultural level of their population, consequently represents the characteristic of the competitiveness of any country. The level of development of higher education affects both the current state of the country's economy and presents a lever for growth of its effectiveness in the future. Given this, the evaluation of the competitiveness of higher education in Ukraine at current stage is very important, as a factor of overcoming the crisis and the formation of the prerequisites for economic growth in the future.

Higher education, in general, forms the intellectual component of human capital, which under conditions of

Corresponding author:

${ }^{1}$ Department of Economics and Management, Kirovohrad National Technical University.

E-mail: ilona.tsarenko@yandex.ua 
the innovative transformation of market environment is a key for certainly actualizes studying this issue.

The problems of competitiveness of higher education in the context of the globalization transformations are studied by scientists from different countries, each of which is aimed at a particular sphere of research in this field, in particular: N.M. Avshenyuk analyses the socioeconomic determinants of the development of the transnational higher education and indicates, that it's the main indicator in the current conditions is rather rapid growth of the international academic mobility of students (Avsheniuk, 2011), N.I. Konstantyuk characterizes the basic principles of improving competitiveness of higher education in view of the conditions of formation of the global economy (Konstantiuk, 2013), T.M. Nogulich examines the factors of globalization of regional development, paying attention to the positive and negative effects of the globalization for the social sphere and its manifestations in higher education (Nosulich, 2009); T.H. Poluhtovych determines, that the integration of higher education under the conditions of globalization requires the relevant reforms, which are based on the priority the innovation - the susceptibility to innovation and the ability to reproduce them in educational practice (Polukhtovych, 2012); I.G. Utyuzh defines the main directions of globalization in higher education, highlighting the main factors and the signs of manifestation (Utiuzh, 2011).

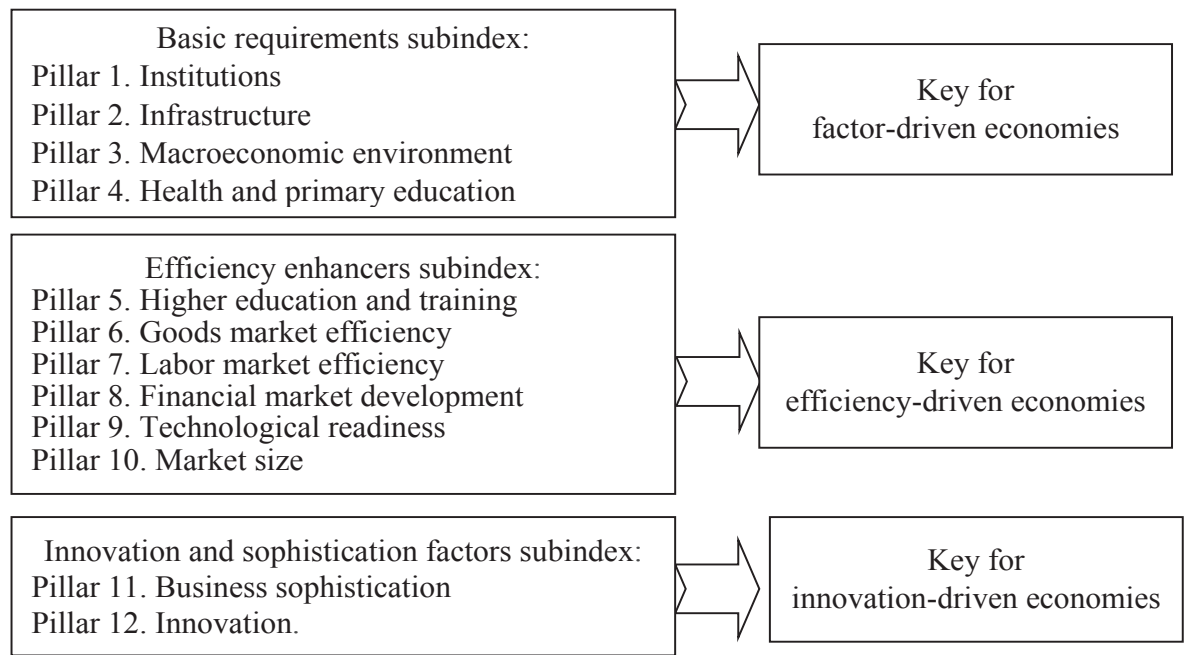

Fig. 1. The components of the Global Competitiveness Index

Source: is composed by the author on the basis the source (Proekt fondu «Efektyvne upravlinnia»)

Table 1

The dynamics of pillar "Higher education and training" of the Global Competitiveness Index

\begin{tabular}{|c|c|c|c|c|c|c|c|c|c|c|c|c|c|c|}
\hline \multirow{2}{*}{ Country/Economy } & \multicolumn{2}{|c|}{2008} & \multicolumn{2}{|c|}{2009} & \multicolumn{2}{|c|}{2010} & \multicolumn{2}{|c|}{2011} & \multicolumn{2}{|c|}{2012} & \multicolumn{2}{|c|}{2013} & \multicolumn{2}{|c|}{2014} \\
\hline & Rank & Score & Rank & Score & Rank & Score & Rank & Score & Rank & Score & Rank & Score & Rank & Score \\
\hline The USA & 5 & 5,67 & 7 & 5,57 & 9 & 5,64 & 13 & 5,58 & 8 & 5,72 & 7 & 5,75 & 7 & 5,82 \\
\hline Japan & 23 & 5,08 & 23 & 5,06 & 20 & 5,28 & 19 & 5,27 & 21 & 5,28 & 21 & 5,28 & 21 & 5,44 \\
\hline China & 64 & 4,05 & 61 & 4,09 & 60 & 4,24 & 58 & 4,34 & 30 & 4,64 & 70 & 4,23 & 65 & 4,42 \\
\hline Switzerland & 7 & 5,60 & 6 & 5,60 & 4 & 5,79 & 3 & 5,80 & 3 & 5,90 & 4 & 5,88 & 4 & 5,98 \\
\hline France & 16 & 5,37 & 15 & 5,30 & 17 & 5,36 & 20 & 5,24 & 27 & 5,14 & 24 & 5,21 & 28 & 5,26 \\
\hline United Kingdom & 18 & 5,27 & 18 & 5,17 & 18 & 5,34 & 16 & 5,47 & 16 & 5,57 & 17 & 5,45 & 19 & 5,5 \\
\hline Denmark & 2 & 5,98 & 2 & 5,90 & 3 & 5,84 & 6 & 5,75 & 14 & 5,59 & 14 & 5,54 & 10 & 5,68 \\
\hline Poland & 34 & 4,64 & 27 & 4,82 & 26 & 5,00 & 31 & 4,95 & 36 & 4,92 & 37 & 4,88 & 34 & 5,04 \\
\hline Czech Republic & 25 & 4,98 & 24 & 5,05 & 24 & 5,11 & 30 & 4,95 & 38 & 4,87 & 39 & 4,85 & 35 & 5,02 \\
\hline Finland & 1 & 6,07 & 1 & 5,97 & 1 & 6,06 & 1 & 6,09 & 1 & 6,18 & 1 & 6,27 & 1 & 6,22 \\
\hline Romania & 52 & 4,29 & 52 & 4,30 & 54 & 4,47 & 55 & 4,42 & 59 & 4,36 & 59 & 4,41 & 58 & 4,63 \\
\hline Ukraine & 43 & 4,46 & 46 & 4,38 & 46 & 4,61 & 51 & 4,58 & 47 & 4,70 & 43 & 4,75 & 40 & 4,93 \\
\hline Russian Federation & 46 & 4,40 & 51 & 4,30 & 50 & 4,55 & 52 & 4,54 & 52 & 4,59 & 47 & 4,66 & 39 & 4,96 \\
\hline Kazakhstan & 59 & 4,12 & 59 & 4,13 & 65 & 4,20 & 65 & 4,18 & 58 & 4,37 & 54 & 4,52 & 62 & 4,51 \\
\hline Azerbaijan & 80 & 3,76 & 72 & 3,88 & 77 & 3,96 & 75 & 4,01 & 89 & 3,91 & 87 & 4,00 & 90 & 3,9 \\
\hline Georgia & 84 & 3,72 & 84 & 3,70 & 90 & 3,74 & 88 & 3,87 & 93 & 3,82 & 92 & 3,79 & 92 & 3,89 \\
\hline Armenia & 94 & 3,43 & 96 & 3,46 & 91 & 3,66 & 76 & 4,01 & 70 & 4,22 & 77 & 4,18 & 75 & 4,20 \\
\hline
\end{tabular}

Source: is composed by the author on the basis the source (Vsesvitniy ekonomichnyi forum) 


\section{Higher education} at Global Competitiveness Index

Thelevel of development of higher education as a factorin the competitiveness of the economies of the world is represented in many international rankings. The most common of these is the Global Competitiveness Index (GCI) - a global research and accompanying its ranking countries by the indexes of economic competitiveness. GCI is calculated according to the methodology of the World Economic Forum (WEF), and is based on the combination of common statistics and the results of a global survey of corporate executives.

The Global Competitiveness Index is composed of 113 variables that describe in detail the competitiveness of countries at different levels of economic development and are combined into 12 pillars that determine the national competitiveness (Vilna entsyklopediya).

In general, the components that form an individual global index of competitiveness for each country can be reduced to 12 (fig. 1).

On the basis of the purpose of the research, we pay attention to such factor (fig. 1) as higher education, which represents the component that improves the efficiency of the economy of any country.
Then, we consider it appropriate to analyse the dynamics of the given component "Higher education and training" of the Global Competitiveness Index (Table 1). Analysing the table 1, we observe that in the last five years the highest index of higher education and training belongs to Finland, the score of which, in the dynamics, significantly increases. Only at the end of 2014 is observed a slight decrease of the index. The position of the USA is variable: falling of the index from 5.67 in 2008 to 5.58 in 2011 and its increasing from 2012 till 2014 to 5.82 . The weakening of the position is observed in Denmark, which during 2008-2010 was part of the three countries with the highest index, whereas during the recent years Singapore has strengthened, as it is a country of the group of newly industrialized states - from 5.56 (8) in 2008 to 6, 09 (2) in 2014.

Looking at the pillars of higher education and training in Poland, it is concluded that its value during the analysed period is dynamically changing - namely, at the end of 2014 the country took the same position as in 2008 - 34th place, while the score of the index started to restore the own positive dynamic only at the end 2014, which indicates the relative instability and deteriorating of competitiveness.

The value of the pillar in the dynamics of Ukraine for clarity portrayed as Fig. 2.

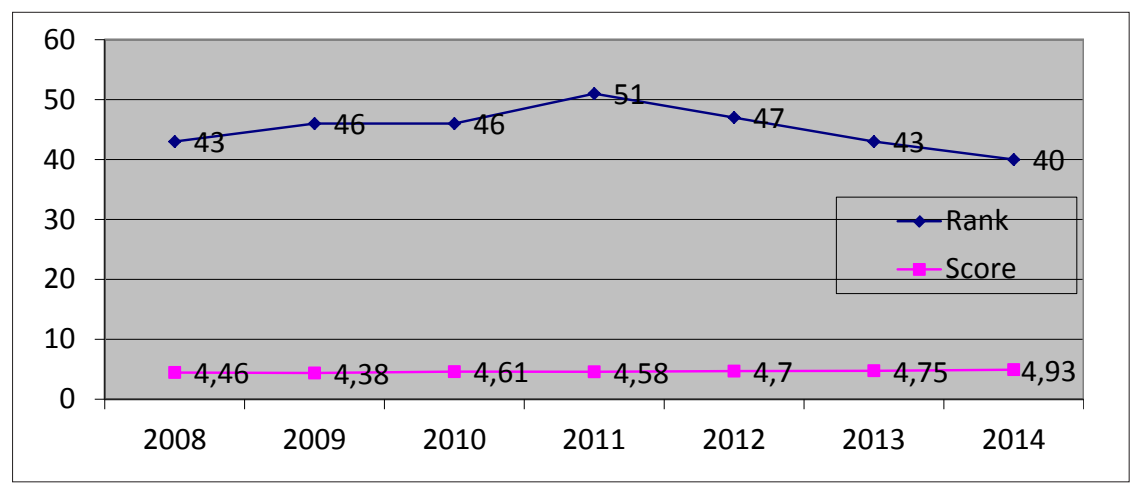

Fig. 2. The dynamics of pillar "Higher Education and training" of the Global Competitiveness Index of Ukraine

Source: is composed by the author on the basis the source (Vsesvitnii ekonomichnyi forum)

Table 2

The detailed comparative characteristic of variables of the pillars "Higher Education and training" of the Global Competitiveness Index of Ukraine and Finland in 2014

\begin{tabular}{|c|c|c|c|c|c|c|}
\hline \multirow{2}{*}{$\begin{array}{l}\text { The name of the variable of the pillar: } \\
\text { «Higher education and training» } \\
\text { of the Global Competitiveness Index in detail }\end{array}$} & \multicolumn{2}{|c|}{ Ukraine } & \multicolumn{2}{|c|}{ Finland } & \multicolumn{2}{|c|}{ Ratio } \\
\hline & Value & Rank & Value & Rank & Relative & Absolute \\
\hline Secondary education enrollment, gross \% & 97,8 & 41 & 107,7 & 14 & 1,10 & -27 \\
\hline Tertiary education enrollment, gross \% & 79,7 & 13 & 93,7 & 4 & 1,18 & -9 \\
\hline Quality of the education system & 3,7 & 72 & 5,9 & 2 & 1,59 & -70 \\
\hline Quality of math and science education & 4,8 & 30 & 6,3 & 2 & 1,31 & -28 \\
\hline Quality of management schools & 3,9 & 88 & 5,6 & 12 & 1,44 & -76 \\
\hline Internet access in schools & 4,3 & 67 & 6,5 & 4 & 1,51 & -63 \\
\hline Availability of research and training services & 3,9 & 84 & 5,9 & 6 & 1,51 & -78 \\
\hline Extent of staff training & 3,8 & 92 & 5,3 & 5 & 1,39 & -87 \\
\hline
\end{tabular}

Source: is composed by the author on the basis the source (Vsesvitniy ekonomichnyi forum) 
We observe, that the rank of index increases, and in 2014 was the highest, including the score of 4.93 . This growth enhances the competitiveness of the economy, because this pillar is "Efficiency enhancers", which is especially important for Ukraine as a country, which is approaching the second stage of the development (by the WEF's methodology).

Then, by comparing with the highest value unifying pillar of higher education and training, we consider the variables that includes Ukraine and the country-leader in 2014 - Finland (Table 2).

As can be observed from the table 2, the variables of Finland are exceeding the components of Ukraine almost 1.5 times, the exception is only such component as 'secondary education enrolment', that for Ukraine is about 97.8. This indicates that $2.2 \%$ of the population has no education. Concerning the high education, the coverage in Ukraine is only $79.7 \%$, which is $14 \%$ less than in Finland. Given these differences, we consider it appropriate to analyse the main macroeconomic indicators of both countries (Table 3).

Table 3

The comparative characteristics

of the main macroeconomic indicators of Ukraine and Finland in 2014

\begin{tabular}{|l|c|c|c|}
\hline \multicolumn{1}{|c|}{ Key indicators } & Ukraine & Finland & The relative ratio \\
\hline Population (millions) & 45,4 & 5,5 & 0,1 \\
\hline GDP (US\$ billions) & 177,8 & 256,9 & 1,4 \\
\hline GDP per capita (US\$) & 3919 & 47129 & 12,0 \\
\hline
\end{tabular}

Source: is composed by the author on the basis the source (Vsesvitniy ekonomichnyiforum)

A key indicator of Finland - the GDP per capita is 12 times higher than in Ukraine. This may indicate a higher standard of living in the country and, as a result, more opportunities for population.

Table 4 presents the main indicators, which characterize the level of funding the higher education, gets in different countries.

Looking at Table 4, observe the following:

1. The share of total expenditure on education in total gross domestic product of most countries ranges from 3.8 to $5.9 \%$. The relative value for Ukraine is about $5.3 \%$, although in Article 61 of the Law of Ukraine about Education states that the budgetary allocations to the education sector should be not less than $10 \%$ of GDP. However, in view of the analysis of world practice, consider that this norm is enough inflated because in the world there is only a few countries which expend on the education more than $10 \%$ of national income, mainly it concerns the small island countries, which are located in the Pacific Ocean or the Caribbean.

2. Concerning the total public expenditure on education, despite the fact that the value of this indicator as a percentage almost the same, the actual costs are various due to the differences in GDP per capita, especially noticeable on the example of the developed countries.

3. Given the different value of GDP, and as a result the total expenditures on the education, one can observe the significant differences in spending per student, particularly in Ukraine. This value is only 3121 USD per year, while in other countries it is several times over, from 9000 to 30000 USD. In the neighbouring Russian Federation, where about 10.7 thousand Ukrainians study the costs per one student are 7749 USD.

In addition, the reflection of the financial provision of the higher education of any country is the material and technical base of universities. For example, analyse such indicators as the number of personal computers per 100 persons and them the quantities the Internet users.

5 . We can see the prior point when analysing indicators of PC owners per 100 persons and Internet users per 100 persons. Ukraine remains at the level below average according to global tendencies. The value of these indicators for Ukraine is below the world average, which characterizes the lack of financial provision in order to create an appropriate material and technical base.

Concerning the expenditure on the education of the country-leader pillar "Higher Education and Training" of the Global Competitiveness Index, the costs of Finland to the education are $6.8 \%$ of GDP and $12.1 \%$ of total government expenditure. This indicator is slightly higher than the average for the European Union.

In addition, the level of competitiveness of higher education in any country, as a reflection of its effectiveness,

Table 4

The main indicators the level of Funding the Higher Education by different countries

\begin{tabular}{|l|c|c|c|c|c|c|c|c|}
\hline \multicolumn{1}{|c|}{ Indicators } & Ukraine & $\begin{array}{c}\text { Russian } \\
\text { Federation }\end{array}$ & USA & Germany & France & Japan & China & Poland \\
\hline GDP per capita (US\$) & 3870 & 19833 & 46588 & 37430 & 34256 & 33785 & 7519 & 19908 \\
\hline Total expenditure on education, \% of GDP & 5,3 & 4,1 & 5,6 & 4,6 & 5,9 & 3,8 & 4 & 5,1 \\
\hline Public expenditure on higher education \% of GDP & 2,0 & 1,2 & 1,0 & 1,1 & 1,3 & 0,5 & - & 1,1 \\
\hline Total expenditure on education per capita (US\$) & 205,1 & 813,1 & 2515,7 & 1721,8 & 2021,1 & 1283,8 & 300,8 & 1015,3 \\
\hline Expenditure per student per year (US\$) & 3121 & 7749 & 29201 & 15711 & 14642 & 15957 & - & 19269 \\
\hline Personal computers per 100 population, units & 4,5 & 13,3 & 80,6 & 65,6 & 63,1 & 40,7 & 5,7 & 16,9 \\
\hline Internet users per 100 population, units & 44,6 & 43,4 & 74,2 & 82,5 & 77,5 & 77,6 & 34,4 & 62,5 \\
\hline
\end{tabular}

Source: is composed by the author on the basis the source (UNDP, 2014)

* Note: Data for 2012 
demonstrates the indicator of mobility of the students. That shows the quantities of students, which to obtain more quality education, are ready to move to another country, in other words, it can be called the lost amount of potential students for national universities.

Then, we analyse the connection of the index of mobility with the country's position in the Global Competitiveness Index in the aspect of higher education. In 2014 Ukraine was 40th in the rankings of GCI, while the quantities of potentially lost Ukrainian students, which moved to study abroad is 39.63 thousand people, which is 1.4 of the total; Russian Federation is located above Ukraine - on the 39 position, and the quantity of students is $51.17(0.7 \%)$.

Finland, which is in first place in the ranking, has the lost quantity of domestic students in the amount of 8.212 thousand. For Denmark, for example (10th place, but during 2008-2010 the country was in the top three), it is typical, that 5.767 thousand of domestic students prefer the foreign universities. From China, which maintains the 65 th position at the rank, 694.041 thousand persons moved elsewhere.

\section{Rating systems and Ukraine}

Today, one of the most common methods of comparative evaluation of the universities in the world are rating systems. Among the most influential world rankings are the Shanghai ranking, ranking QS and Times Higher Education World University Ranking.

The leaders of the Shanghai ranking are the universities of the UK and the USA. In 2014, the ranking was led by Harvard University, at the second position was Stanford University, closed the top three - Massachusetts Institute of Technology, the fourth - University of CaliforniaBerkeley, the fifth position headed University of Cambridge (UNESCO). However, the top five universities of QS World University Rankings look different, in particular: Massachusetts Institute of Technology (USA), two second places - University of Cambridge (UK) and Imperial College of London (UK), the fourth - Harvard University (USA) two fifth positions - University of Oxford (UK) and University College of London (UK) (Academic Ranking of World Universities).

Concerning the representation of Ukraine in international rankings, for example, in 2014, in comparison with the past, the number of Ukrainian universities that were included to the world ranking QS had six universities, two of them got into the top 500 ranking. Those were Taras Shevchenko National University of Kyiv (placed 421-430) and V. N. Karazin Kharkiv National University (placed 481-490). In addition, by the results of the QS World University Rankings 2014/15 the rating also includes National Technical University of Ukraine "Kyiv Polytechnic Institute" (place 551-600), Sumy State University (place 651-700), Donetsk National University (701+ place) and the National Technical University "Kharkiv Polytechnic
Institute" (701+) (Tsarenko, 2014). Note, that in 2013 the rating included only four Ukrainian universities, among the newcomers in 2014 were V.N. Karazin Kharkiv National University and Sumy State University.

In this regard, given the aforementioned circumstances and international experience, the modern directions of increasing the competitiveness of higher education should be based on the following principles:

- public funding should primarily focus on the directions of training, which are required for the development of the national economy;

- conditions of the access to the quality of higher education should conform the strategic interests of the country, which lie in the fact that to such education, in the first place, could get talented citizens, regardless of their place of residence and income of their families;

- level of public funding of universities should depend on the quality level of the training specialists, but the state should at the same time stimulate increasing the quality of training in the regional universities in order to increase the accessibility to quality higher education in low income levels of the population;

- creation of positive investment climate in the sphere of higher education to improve the efficiency using of budget funds and funds of the private investors;

- bringing of price level on the educational services of university to the level of real cost of education, taking into account the raising salaries of the teaching staff and improving the necessary material and technical provision of the training process;

- creating the real economic mechanisms and ensuring accessibility quality higher education for the talented young persons, by means of the diversified model of financial provision of this process, using of direct budgetary financing of the training of students in higher education, and the use of instruments of real preferential loans, grants, etc.;

- stimulation for the employers and local governments to participate in the financing of the establishments of higher education and the training of personnel for internal needs for their own means;

- strengthening the monitoring for graduates of the universities, who have studied for budgetary funds to improve the effectiveness of this process and the establishment of mechanisms for the targeted training specialists on order from certain organizations or enterprises;

- transformation of the model of funding science in accordance to the public priorities and the level of quality of the most researches in universities, stimulation of the development of scientific research and innovation activities;

- stimulating the cooperation among the universities, research institutions and the corporate sector in the sphere of the scientific research, organization of the manufacturing practices, conduction of the scientific and practical seminars and conferences for the purpose 
of attracting the modern knowledge in the educational process (Levchenko, 2009);

- intensifying the participation of universities in the world rankings and international cooperation, improving the quality of education to the European standards, increasing the academic mobility of teachers and students.

\section{Conclusions}

Thus, evaluating the level of competitiveness is a multifaceted research of different orientations and depends on many factors, from the country's macroeconomic indicators to directly generalizing the characteristics of the work process of universities, their material base, the quality of teaching, etc. In the context of international comparisons Ukraine among 132 countries takes 40th place that is top 50 countries with the highest ranking of the competitiveness of higher education and training.
This position for Ukraine is stable, with the exception of 2011 , when the position was reduced to 51 in the rankings. Furthermore, in 2014 Ukraine's rating has increased in comparison with other years. Although, due to the fact that, for example, such countries as Puerto Rico (rank 27, score of index 5.27), Qatar (rank 38, score of index 4.99) are assigned the higher ranking positions, the government needs to address some issues with Ukraine's position. The state has to eliminate the problems and strengthen the competitive position. First of all it concerns improving the quality of education, level of training, dissemination of research and training services, transfer of educational and professional knowledge, increasing academic mobility of teachers and students. Therefore, it is necessary to develop an integrated evaluation methodology of the competitive positions of higher education in Ukraine, so it can become the perspective direction for further research in this sphere.

\section{References}

Avsheniuk, N.M. (2011). Sotsialno-ekonomichni determinanty rozvytku transnatsionalnoi vyshchoi osvity na zlami XX-XXI stolit - Porivnialna profesiina pedahohika, № 1, p. 52-61.

Konstantiuk, N.I. (2013). Osnovni zasady pidvyshchennia konkurentospromozhnosti vyshchoi osvity Ukrainy v umovakh formuvannia hlobalnoi ekonomiky - Stalyi rozvytok ekonomiky, Mizhnarod.nauk-vyrob. zhurnal, № 3, p. 26-28.

Nosulich, T.M. (2009). Hlobalizatsiini chynnyky rehionalnoho rozvytku-sotsialnyi vektor proiavu - Stratehiia ekonomichnoho rozvytku Ukrainy, Vol. 24-25, p. 141-144.

Polukhtovych, T.H. (2012). Intehratsiia vyshchoi osvity Ukrainy v umovakh hlobalizatsii - Sevastopol, Visnyk SevNTU, Vol. 127, p. 184-187.

Utiuzh, Y.H. (2011). Hlobalyzatsyia v systeme vissheho obrazovanyia - Humanitarnyi visnyk ZDIA, № 47, p. 51-65.

Vilna entsyklopediia. [Electronic resource]. - Retrieved from: http://uk.wikipedia.org/wiki/

Proekt fondu «Efektyvne upravlinnia» «Competitive Ukraine». [Electronic resource]. - Retrieved from: http://competitiveukraine.org.ua/reports/2013

Vsesvitnii ekonomichnyi forum. [Electronic resource]. - Retrieved from: http://www.weforum.org/

UNDP (2014) “Human Development Report”, [online], availableat. [Electronic resource]. - Retrieved from: http://hdr.undp.org/en/media/HDR_2014.pdf

Global Flow of Tertiary-Level Students. [Electronic resource]. - Retrieved from: http://www.uis.unesco.org/ Education/Pages/international-student-flow-viz.aspx

Academic Ranking of World Universities. [Electronic resource]. - Retrieved from: http://www.shanghairanking. com/World-University-Rankings/Swiss-Federal-Institute-of-Technology-Zurich.html

QS Worldwide University Rankings. [Electronic resource]. - Retrieved from: http://www.topuniversities.com/ subject-rankings

Levchenko, O.M. (2009). Profesionalnyi potentsial: rehuliatorni mekhanizmy innovatsiinoho rozvytku Kirovohrad, KOD, 375 p.

Tsarenko, I.O. (2014). Reitynhovi systemy ranzhuvannia vyshchykh navchalnykh zakladiv: ukrainski ta svitovi metodyky - Naukovi pratsi Kirovohradskoho natsionalnoho tekhnichnoho universytetu. Ekonomichni nauky, p. 56-66.

\section{Илона ЦАРЕНКО}

КОНКУРЕНТОСПОСОБНОСТЬ ВЫСШЕГО ОБРАЗОВАНИЯ В СООТВЕТСТВИИ С МЕЖДУНАРОДНЫМ ИЗМЕРЕНИЕМ

Аннотация. Целью исследования является осуществление оценки конкурентоспособности высшего образования по сравнению с зарубежными странами и под влиянием глобализации рыночной среды. Оценка уровня конкурентоспособности системы высшего образования Украины на современном этапе под влиянием глобализационных преобразований и в призме международных сравнений исследована не в достаточной степени, на что и сосредоточено данное исследование. Методика. Исследование основано на 
сравнении данных, которые изложены в международных отчетах об конкурентоспособности стран мира, в частности касательно высшего образования. Заранее сделан анализ степени изучения проблематики конкурентоспособности высшего образования в работах ученых. Практическое значение. Описаны основные компоненты столба «Высшее образование и обучение» Глобального индекса конкурентоспособности, а именно: охват средним образованием, охват высшим образованием, качество системы образования, качество преподавания математики и естественно-научного образования, качество школ менеджмента, доступ к интернету в школах, наличие научно-исследовательских и учебных услуг, степени подготовки персонала. Сделан анализ динамики показателя «Высшее образование и обучение» Глобального индекса конкурентоспособности для Украины и других стран, который показал следующее: за последние пять лет самый высокий показатель высшего образования и профессиональной подготовки принадлежит Финляндии, показатель которой, в динамике, значительно возрастает, касательно Украины, то Украина среди 132 стран занимает 40-е место из топ-50 стран с наивысшим рейтингом конкурентоспособности высшего образования и профессиональной подготовки, эта позиция для Украины является стабильной, за исключением 2011 года, когда позиция была снижена до 51 места в рейтинге. Кроме того, в 2014 году рейтинг Украины увеличился по сравнению с другими годами. После чего более подробно были проанализированы макроэкономические показатели Украины и Финляндии. Были исследованы основные показатели уровня финансирования высшего образования в разных странах (общие расходы на образование, государственные расходы на высшее образование к ВВП, общий объем расходов на образование в расчете на душу населения, расходы на одного учащегося в год, число персональных компьютеров на 100 человек населения, интернет-пользователей на 100 человек населения), за результатами сделаны соответствующие выводы. Рассмотрены наиболее влиятельные мировые рейтинги, такие как Шанхайский рейтинг, рейтинг QS и Times Higher Education World University. Предложен анализ позиций украинских высших учебных заведений, которые входят в такие рейтинги, а именно - Киевский национальный университет имени Тараса Шевченка (421-430 позиции) и Харьковский национальный университет имени В.Н. Каразина (481-490 позиции). Кроме того, исследованы принципы повышения конкурентоспособности высшего образования. Значение/ оригинальность. Полученные результаты показали необходимость разработки методики усиления конкурентных позиций высшего образования Украины. 